\title{
Biology and distribution of Agrilus macer LeConte (Coleoptera: Buprestidae), a species associated with sugarberry (Celtis laevigata Willd.) mortality in the southeastern USA
}

\author{
Emilee M. Poole ${ }^{1}$ (D) Michael D. Ulyshen ${ }^{2} \cdot$ Scott Horn $^{2} \cdot$ Michelle Cram $^{2} \cdot$ Rabiu Olatinwo $^{3} \cdot$ Stephen Fraedrich $^{2}$
}

Received: 15 June 2018 / Accepted: 18 December 2018 / Published online: 23 January 2019

(C) This is a U.S. Government work and not under copyright protection in the US; foreign copyright protection may apply 2019

\begin{abstract}
- Key message Agrilus macer is attacking sugarberry trees in the southeastern USA, a region from which few specimens have been previously collected. Despite attacking at high densities, this species appears to be a secondary pest, and there is no evidence it carries harmful fungal pathogens.

- Context Because the genus Agrilus Curtis includes significant forest pests, the association of a poorly known species, Agrilus macer LeConte, with unexplained sugarberry (Celtis laevigata Willd.) mortality in the southeastern USA is a cause for alarm.

- Aims This study sought to investigate the distribution and biology of A. macer and determine whether the species is a primary cause of observed tree mortality.

- Methods Through a series of studies and literature searches, we documented aspects of A. macer biology and distribution while focusing on egg-laying behavior and searching for fungal pathogens associated with oviposition sites.

- Results A. macer appears to be widely distributed throughout the southern USA, but most records are from Texas and Louisiana. Egg mass densities up to 1.2 masses per $10 \mathrm{~cm}^{2}$ (equivalent to $\sim 1.9$ eggs per $\mathrm{cm}^{2}$ ) were observed on trunks, branches, and exposed roots of dying C. laevigata trees in our study area, with an average of 16 eggs per mass. Fungi isolated from discolored sapwood around larval galleries did not cause defoliation, dieback, or mortality of sugarberry in inoculation trials.

- Conclusion Our findings suggest that A. macer is a secondary pest on sugarberry and does not transmit harmful fungal pathogens.
\end{abstract}

Keywords Agrilus $\cdot$ Eggs $\cdot$ Egg masses $\cdot$ Fungal isolation $\cdot$ Oviposition $\cdot$ Saproxylic

\section{Handling Editors: Aurélien Sallé \& Christophe Bouget}

Contributions of the co-authors Michael Ulyshen conceived of the studies on the distribution and biology of $A$. macer while Rabiu Olatinwo and Michelle Cram led the search for potential pathogens. Field work was performed by Michael Ulyshen, Scott Horn, Emilee Poole, Stephen Fraedrich, and Michelle Cram, while Rabiu Olatinwo isolated fungi from some samples and sequenced fungal isolates. Michelle Cram and Stephen Fraedrich conducted pathogenicity tests on fungi. Emilee Poole and Michael Ulyshen analyzed the results and wrote the paper with contributions from all co-authors.

This article is part of the topical collection on Entomological issues during forest diebacks

Emilee M. Poole

emp66194@uga.edu

1 Department of Entomology, University of Georgia, Athens, GA 30602, USA

2 USDA Forest Service, Southern Research Station, Athens, GA 30602, USA

3 USDA Forest Service, Southern Research Station, Pineville, LA 71360, USA

\section{Introduction}

Insects and diseases are often found to play a significant role in forest health issues, and the movement of these organisms among and within continents has had disastrous consequences for a number of tree species. Some insect taxa have been repeatedly implicated in major episodes of tree mortality. Within North America, for example, a number of nonnative buprestid species belonging to the genus Agrilus Curtis have been responsible for major losses of Fraxinus (A. planipennis Fairmaire), Quercus (A. auroguttatus Schaeffer), and Sapindus (A. prionurus Chevrolat). Other buprestid species cause losses within their native range such as the damage seen by outbreaks of A. bilineatus Weber on Quercus and A. anxius Gory on Betula (Barter 1957; Bauer et al. 2014; Billings et al. 2014; Coleman and Seybold 2016; Haack 2006; Haack and Benjamin 1982; Muilenburg and Herms 2012). Additionally, concern over losses of Fraxinus from A. planipennis and 
Quercus from A. biguttatus, Fab. and A. bilineatus is increasing in Europe with the growing awareness of the damaging abilities of Agrilus species (Baranchikov et al. 2008; Brown et al. 2015; Hizal and Arslangundğdu 2018; Reed et al. 2018). Although few Agrilus species act as primary pests, a close association between an Agrilus species and an emerging forest health issue should not be overlooked. The purpose of this study was to explore what role a largely unknown species of Agrilus, A. macer LeConte, is playing in the mortality of sugarberry (Celtis laevigata Willd., Cannabaceae) in the southeastern USA.

Trees belonging to the genus Celtis grow throughout North America including Mexico. Although ranges overlap considerably in Texas and other south-central states, three species (C. lindheimeri Engelmann ex K. Koch, C. pallida Torrey, and $C$. reticulata Torrey) are primarily western species whereas three others ( $C$. laevigata Willd., C. occidentalis L., and C. tenuifolia Nuttall) are largely concentrated in the east (www.eFloras.org, accessed Aug. 2018). In addition to these native species, species of non-native Celtis, such as $C$. sinensis Pers., have become naturalized in North America. Sugarberry commonly grows on floodplains and along rivers and streams, where it thrives as a dominant or codominant member of hardwood forests (Duncan and Duncan 1988; Samuelson and Hogan 2003; Tirmenstein 1990). Sugarberry can dominate disturbed sites, and occasionally pure stands can be found (Ford and Van Auken 1982). In addition to numerous benefits to wildlife as a food source and nesting site, sugarberry is planted as an ornamental tree, and the wood is used for furniture, flooring, or pulp (Duncan and Duncan 1988; Tirmenstein 1990).

Declining health of sugarberry trees (Fig. 1a) was reported around Columbia, South Carolina, in 2009 with symptoms including yellowing leaves and defoliation (Andy Boone, personal communication). Efforts to identify insects or diseases responsible for these symptoms began soon thereafter. In 2011, scientists from the US Forest Service, South Carolina Forestry Commission, and other entomologists and pathologists met to further evaluate reports of symptoms present in other areas of South Carolina. Early inspections reported the larvae of an unidentified species of buprestid beneath the bark of dying sugarberry (Fig. 2a-c), and a large number of lightcolored egg masses were observed on declining trees in some areas (Fig. 1b, c). It was also clear from early observations that areas of sapwood discoloration, usually appearing as streaks, were typically found in association with sites injured by feeding buprestid larvae (Fig. 2d). This is not the first episode of sugarberry mortality to be observed in the southeastern USA. A previous occurrence was reported in Louisiana between 1988 and 1990 (Solomon et al. 1997). Although the presence of Agrilus beetles at low levels was noted in that study, it was concluded they were not the principal cause of the dieback and mortality.
Our objectives in this study were to (1) determine what species of buprestid was infesting sugarberry trees, (2) estimate the density of egg masses on declining sugarberry trees and the number of eggs per mass, (3) investigate the known geographic distribution of the species, (4) describe aspects of its biology, giving special attention to its egg-laying behavior, and (5) determine whether any pathogenic fungi were present in discolored sapwood associated with the beetle activity.

\section{Methods}

\subsection{Study area}

Field work was concentrated along the Savannah River in North Augusta, South Carolina $(33.49,-81.98)$ near the North Augusta Greeneway (hereafter referred to as the Greeneway), a forested area with paved and unpaved recreational trails. The climate of the region is subtropical with an average annual temperature of $17.7^{\circ} \mathrm{C}$ and an average annual rainfall of $1.1 \mathrm{~m}$ (usclimatedata.com, accessed Aug. 2018). It is estimated that $70-80 \%$ of the trees along the Greeneway are sugarberry (MDU, EMP, and Roy Kibler-North Augusta Superintendent of Property Maintenance, personal observation). In 2015, when this study began, large numbers of dying sugarberry could be found on both sides of the river, but the size of the affected area was not determined. Many of the stressed and dying trees at our main study site along the Greeneway were clearly experiencing high densities of buprestid attacks with large numbers of egg masses visible on the bark of trunks, branches, and exposed roots (Fig. 1). The observations and data reported in this study came from a variety of habitats along the Greeneway, ranging from trees growing in mulched beds near the river as well as in adjacent woodlots, some of which were growing on slopes above the floodplain. Other tree species present include Prunus serotina Ehrh., Acer negundo L., Pinus taeda L., Liquidambar styraciflua L., Platanus occidentalis L., Quercus nigra L., and Quercus phellos L.

\subsection{Abundance and distribution of egg masses}

On 6 October 2015, five sugarberry trees of varying diameters and heights were felled in a small woodlot along the Greeneway (Table 1, Fig. 1b). Beginning at a height of $0.5 \mathrm{~m}$ above the ground, $\log$ sections of $20 \mathrm{~cm}$ in length were collected every $2 \mathrm{~m}$ along the primary stem to the furthestmost branch until the last section exceeding $2.5 \mathrm{~cm}$ in diameter was collected. Depending on the height, six to nine log sections were collected from each tree (Fig. 4). The number of egg masses on each section was counted in the laboratory. The length and circumference of each log section were then used 
Fig. 1 Dying sugarberry (a). Felled sugarberry covered with light-colored Agrilus macer egg masses (b). Dark weeping egg masses as larvae penetrate the bark (c). Tree with callus tissue formations overcoming A. macer attack (d). Close-up of failed colonization attempts characterized by circular tissue protruding from the bark (e). (Photos by M. Ulyshen)
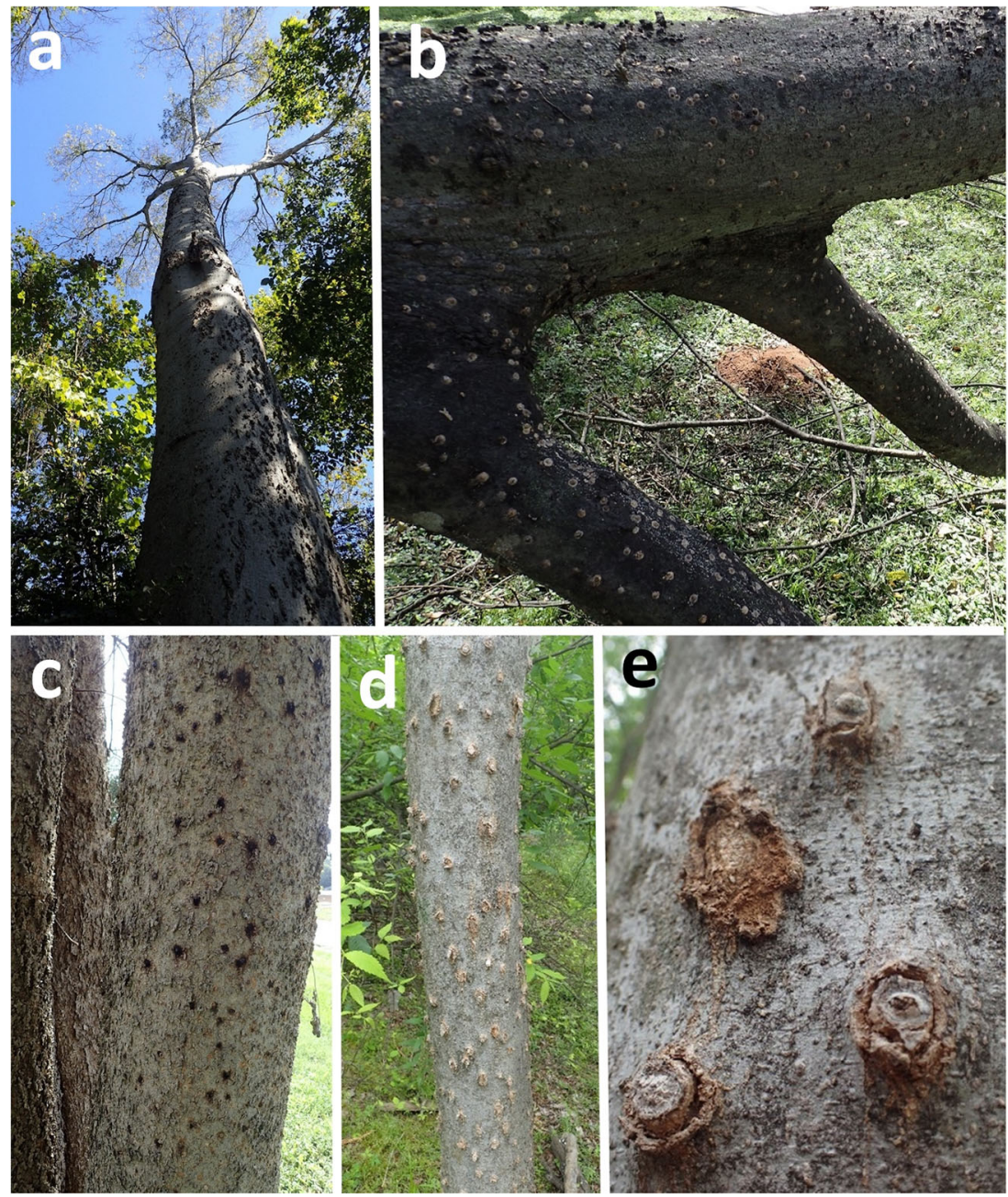

to calculate the number of egg masses per square meter of bark, hereafter referred to as egg mass density (Table 1). The average egg mass density between two consecutive sections was used to estimate the number of egg masses on the intervening $2-\mathrm{m}$ section, thus allowing us to calculate the total number of egg masses on the entire stem (though not including side branches). We also estimated the total number of eggs laid by multiplying the estimated number of egg masses by the average number of eggs per mass (see "Number of eggs per mass" section below). Because the number of egg masses and thus egg mass density varied considerably among the five trees, we standardized egg mass density for each section by dividing by the highest egg mass density measured from any section belonging to the same tree. The highest standardized egg mass density for any tree was therefore 1 . These results were used to determine how egg mass density varied along the length of the bole. The mixed procedure of SAS was used to test whether standardized egg mass density varied with height above the ground with tree included as a random effect.

\subsection{Number of eggs per mass}

Individual egg masses were carefully removed from the bark to count the number of eggs present within each mass. Fresh egg masses were detached from the log sections of the five felled trees corresponding to the following heights: $0.6,2.8,5$, $7.2,9.4,11.6,13.8,16.0$, and $18.2 \mathrm{~m}$. In total, 107 egg masses that still contained unhatched eggs or from which larvae were in the process of tunneling through the bark were included in these counts. The bark layers beneath the egg masses were carefully dissected under a microscope to detect any hatched larvae. The number of unhatched eggs and larvae were totaled to estimate the number of eggs initially present in each egg mass. The mixed procedure of SAS was used to test whether the number of eggs varied with height above the ground with tree included as a random effect.

\subsection{Observations of $A$. macer egg-laying behavior}

During the summer of 2016, the trunks of declining sugarberry trees were observed along the Greeneway to determine 


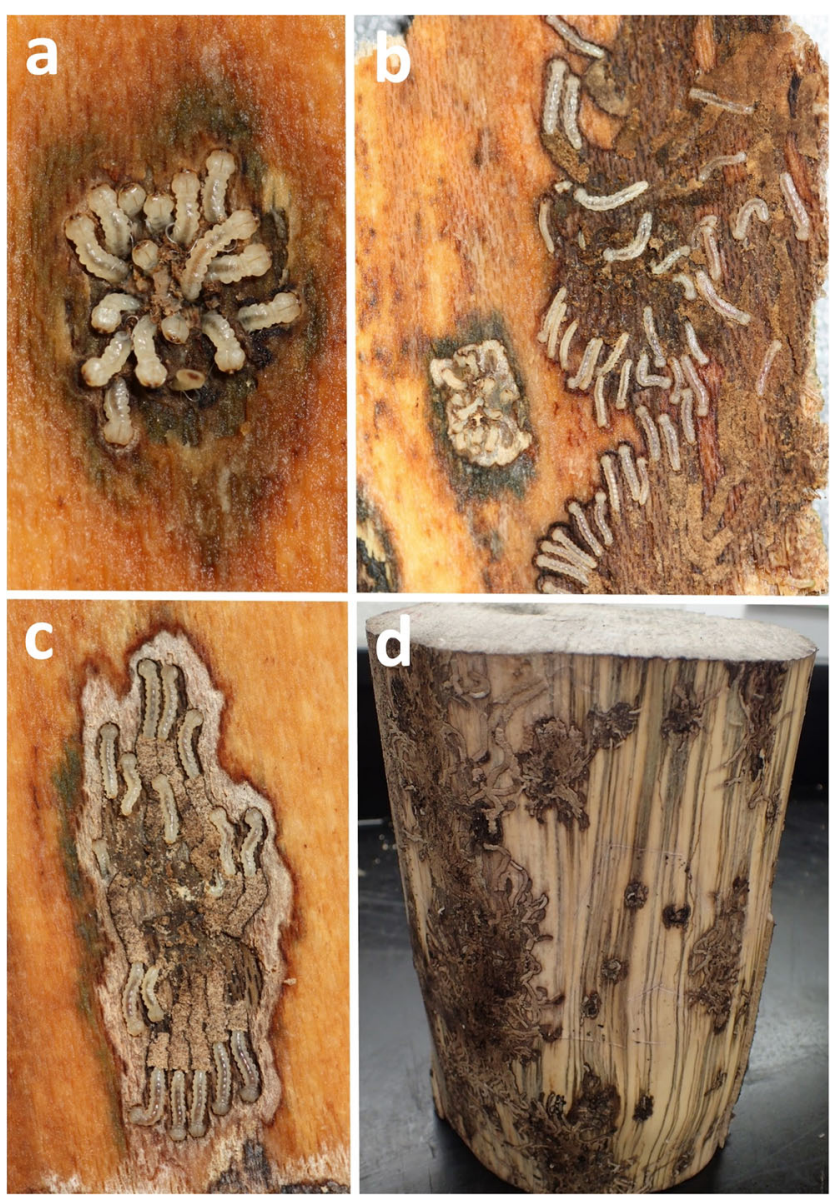

Fig. 2 Agrilus macer larvae from a single egg mass as seen from the underside of bark (a). Feeding A. macer on the underside of bark (b-c). A de-barked log showing multiple colonization points and associated xylem discoloration (d). (Photos by M. Ulyshen)

which species was responsible for the egg masses and to better understand the egg-laying behavior of the species. The observations were made opportunistically between late morning and early afternoon hours, and an effort was made to photograph the sequence of events (Fig. 3).

\subsection{Adult activity period}

We installed traps on 10 declining sugarberry trees in 2016, many with visible $A$. macer egg masses, along the Greeneway to determine the peak activity period for adult $A$. macer. Two brackets were installed on opposite sides of each tree. One bracket received a black Lindgren funnel trap (with eight funnels), whereas the other received a flight intercept trap. The flight intercept trap consisted of two intersecting sheets of clear plexiglass $(20 \times 30 \mathrm{~cm})$ attached above a single Lindgren funnel. Propylene glycol and a few drops of dish soap were used as the killing and preservative agent in both traps; samples were collected every 2 weeks beginning on 16 May 2016 (after leaf expansion) and ending on 9 September 2016.

\subsection{Agrilus macer distribution}

To determine the known distribution of $A$. macer, specimen data were requested from large university and institutional arthropod collections throughout North America (see Acknowledgements). We requested label data from all specimens present in these collections, such as state, county, collection date, and any host information to assist in understanding the distribution and natural history of the species. Photographs were requested to confirm correct identifications of specimens when they came from states with few other records. A. macer is distinguishable in photographs due to the presence of a prominent raised ridge on each elytron. Specimen data were organized by state, county, and collection date and used to determine the known distribution of A. macer within the USA. Collection date information also allowed us to further examine the adult activity period of the species (Fig. 5). Because we were primarily interested in determining whether A. macer is new to the southeastern USA, we limited our search to primarily US records. The range of $A$. macer is not limited to the USA, however. The species occurs in the Lower Rio Grande Valley close to the USA-Mexico border (Vogt 1949) and has also been recorded from Mexico, confirming its presence south of the USA (Harpootlian and Bellamy 2014; Hespenheide et al. 2011).

\subsection{Oviposition behavior of selected Agrilus species}

To understand how the oviposition biology of A. macer compared to other members of the genus, a literature search was

Table 1 Estimated number of Agrilus macer egg masses and eggs laid along the main trunk and the leading branch of five sampled trees

\begin{tabular}{lllcrc}
\hline Tree & Diameter at $0.5 \mathrm{~m}(\mathrm{~m})$ & Length of primary stem $(\mathrm{m})$ & Bark surface area $\left(\mathrm{m}^{2}\right)$ & Estimated number of egg masses & Estimated number of eggs* \\
\hline A & 0.37 & 18.3 & 10.1 & 13,024 & 209,556 \\
B & 0.15 & 11.7 & 3.4 & 637 & 10,249 \\
C & 0.18 & 13.9 & 4.9 & 4609 & 74,159 \\
D & 0.19 & 13.9 & 4.5 & 2480 & 39,903 \\
E & 0.25 & 16.1 & 6.6 & 384 & 6179 \\
\hline
\end{tabular}

*Based on an average of 16.1 eggs per mass. See text for details 
Fig. 3 Oviposition sequence of Agrilus macer. After eggs are deposited on bark, bright green material is deposited (a) before the mass is covered with a tan secretion (b-d) that hardens into a protective covering (e). (Photos by M. Ulyshen)
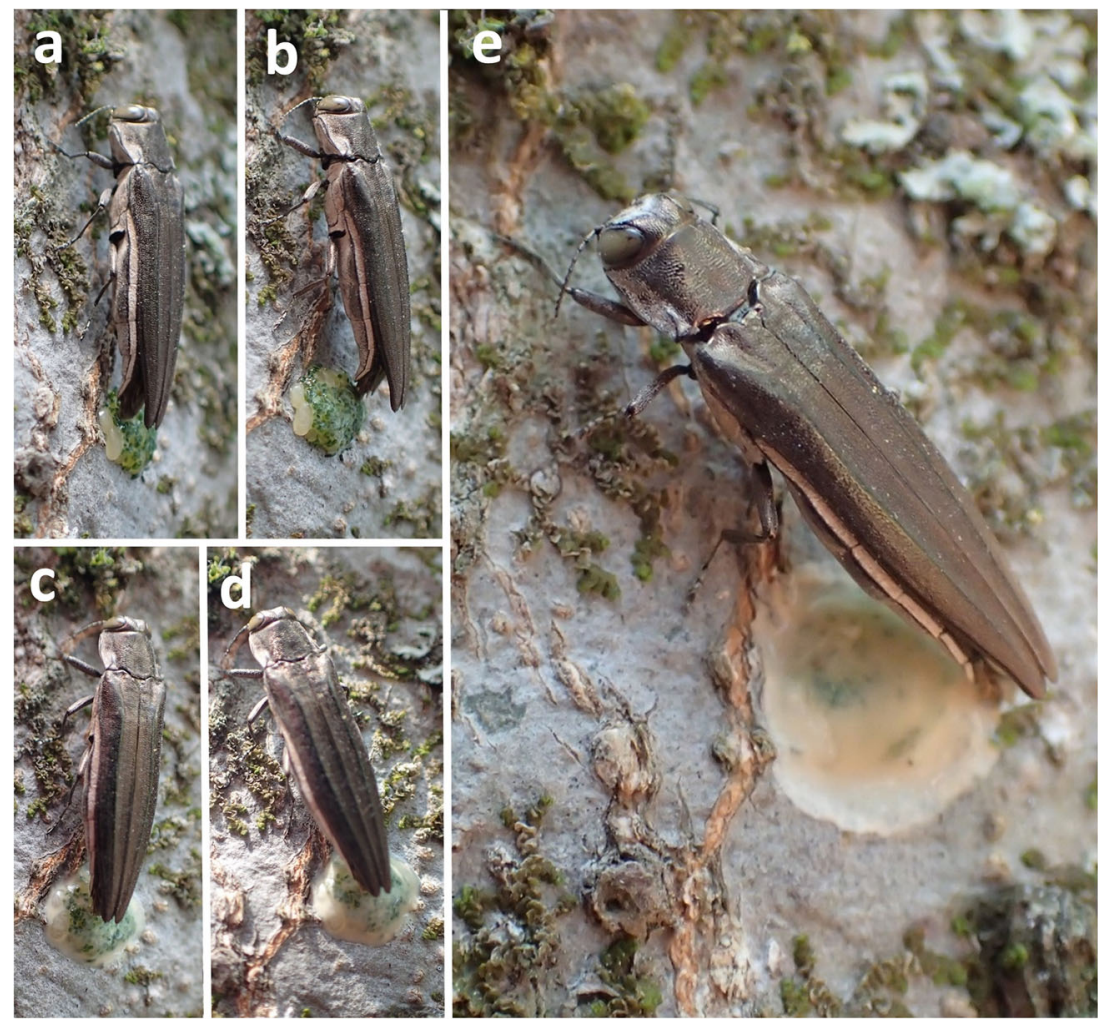

conducted to investigate the habits of other Agrilus species. We specifically looked for information on whether eggs are laid singly or in groups, whether any protective covering is added to the eggs, and whether eggs are laid on the trunk or branches of host trees. Our survey was limited to Agrilus species for which information could be found on egg-laying behavior, including egg number and whether any protective coverings are added to the eggs. Supplementary notes were recorded when resources provided additional information relevant to the oviposition behavior of $A$. macer.

\subsection{Fungal isolation}

Fungal isolations were attempted from areas of discoloration in the sapwood of sugarberry trees that had been attacked by A. macer. The discoloration typically occurred as dark streaks above and below points where A. macer had deposited egg masses and developing larvae were mining areas of the phloem, cambium, and outer sapwood (Fig. 2d). Samples of discolored sapwood were obtained in September 2015 from three infested trees located at Lake Olmstead Park (Augusta, GA) and from eight trees in February 2016 at the Greeneway. Seven additional trees were sampled at the Greeneway in July 2016. A minimum of two areas of discoloration around larval galleries were evaluated for each tree. Fungal isolations were typically attempted within 1 to $10 \mathrm{~cm}$ above and below the larval galleries. The samples were obtained using a handsaw and chisel, debarked, and surface sterilized with either
$1.1 \%$ sodium hypochlorite $(\mathrm{NaOCl})$ solution dip (Lake Olmstead Park) or 95\% EtOH dip for 1 min (Greeneway samples), then rinsed several times in sterile deionized water and blotted dry with sterile paper towels, which were sterilized with an autoclave at $250{ }^{\circ} \mathrm{C}$ at $103.4 \mathrm{kPa}$ for $15 \mathrm{~min}$. Sapwood chips from the Greeneway samples were then plated on malt extract agar (MEA; MP Biomedicals, LLC, Santa Ana, CA, USA), while thinly sliced stem sections from the Lake Olmstead Park trees were placed on sterile moist filter paper in petri dishes. Plates with samples were incubated at $25{ }^{\circ} \mathrm{C}$, and fungi emerging from symptomatic tissue were evaluated. Isolates of potentially pathogenic fungi, as well as fungi routinely observed in the symptomatic samples, were subsequently single-spored and grown on either MEA or potato dextrose agar (PDA; Difco Laboratories Inc., Detroit, MI, USA). Fungal isolates were initially identified by morphological characteristics, and identities were subsequently confirmed by molecular techniques. Isolates were evaluated by PCR amplification and analysis of the internal transcribed spacer (ITS) region from genomic DNA samples extracted from cultures described earlier. Extractions were conducted using the QIAGEN DNeasy Plant Tissue Mini extraction kit (QIAGEN, Valencia, CA) following the manufacturer's instructions, and the DNA extracts were stored at $-20^{\circ} \mathrm{C}$ and used as templates in the PCR amplifications.

PCR amplifications were performed in a $10 \mu$ l reagent mixture containing $5 \mu \mathrm{l}$ TopTaq ${ }^{\mathrm{TM}}$ PCR Master Mix (Qiagen), $1.5 \mu \mathrm{l}$ of a $5 \mu \mathrm{M}$ solution of the forward primer 
ITS1F (5'CTTGGTCATTTAGAGGAAGTAA'3) (Gardes and Bruns 1993) and reverse primer ITS4R (5'TCCTCCGC TTATTGATATGC'3) (White et al. 1990), $1 \mu$ l of $10 \times$ CoralLoad, and $1 \mu \mathrm{l}$ of the DNA template, and amplifications were performed using an Eppendorf Mastercycler ${ }^{\circledR}$ Pro PCR machine. The amplification protocol consisted of initial denaturation at $95{ }^{\circ} \mathrm{C}$ for $3 \mathrm{~min}$, followed by 35 cycles of 35 -s denaturation at $95{ }^{\circ} \mathrm{C}, 55$-s annealing at $58{ }^{\circ} \mathrm{C}$ and 1 -min extension at $72{ }^{\circ} \mathrm{C}$, and a final extension at $72{ }^{\circ} \mathrm{C}$ for $10 \mathrm{~min}$. Gel electrophoresis was performed to examine amplified products by loading $5 \mu \mathrm{l}$ PCR products on $1 \%$ agarose gels. The agarose was stained with ethidium bromide after 20 min. of electrophoresis, and the resulting bands were visualized under UV illumination. PCR products were purified and sequenced at GENEWIZ Inc. (South Plainfield, NJ, USA; http://www.genewiz.com).

\subsection{Pathogenicity tests}

Pathogenicity tests were performed on C. laevigata saplings (approximately 3-5 years old) grown in Georgia at a local nursery (Nearly Native Nursery, Fayetteville, GA, USA). The saplings were approximately $2 \mathrm{~m}$ in height and $18 \mathrm{~mm}$ in diameter at the soil level and were grown in $25-\mathrm{cm}$ pots $(11 \mathrm{~L})$. Isolates from three fungal species, commonly isolated from areas of discolored xylem around A. macer attacks, were tested to determine their effects on sugarberry. On May 3, 2016, saplings were inoculated with one of two fungal treatments, Fusarium neocosmosporiellum O'Donnell and Geiser or Phialemonium dimorphosporum Gams and Cooke, or a sterile PDA plug (control). A second test was established on August 31, 2016, using an isolate of Clonostachys rosea (Link: Fries) Schroers, Samuels, Seifert and W. Gams (syn. Gliocladium roseum; teleomorph, Bionectria ochroleuca) and a sterile PDA control. All isolates were grown in petri dishes with PDA for 3 weeks prior to inoculations. One treatment was applied to the stem of a sapling at $23-25 \mathrm{~cm}$ above the soil line. A 3.5-mm-diameter cork borer was used to remove the bark/phloem, and in order to simulate insect damage, a 1-mm drill bit and drill were used to scrap away the outermost sapwood. A 3.5-mm-diameter plug of inoculum treatment was placed with the mycelial surface down on the damaged sapwood and wrapped with parafilm. There were four replications (four saplings) for each treatment in each test. Inoculated saplings were placed outside in a partially shaded courtyard. Saplings were watered as needed and observed for any outward symptoms of disease until final data measurements were taken on July 27, 2017. The bark, phloem, and cambium were removed from around the inoculation point, and the length of the discolored sapwood above and below the inoculation point was measured. Reisolation of the fungi inoculated in stems was attempted by surface sterilizing (1.1 $\mathrm{NaOH}$ dip) sections of discolored sapwood from around inoculation points and placing them on Nash-Snyder media (Nelson et al. 1983) and PDA amended with 1\% tergitol. Possible differences in the mean lengths of discolored sapwood among the three treatments in test 1 were analyzed using Dunnett's $3 \mathrm{~T}$ test for unequal variances. In test 2 , data was evaluated with a two-sample $t$ test to determine if means were different (SYSTAT 13, Systat Software, Inc., Chicago, IL).

\section{Results}

\subsection{General observations}

When we first visited the Greeneway in 2015, there were numerous sugarberry trees at all stages of decline, including many dead trees. Dying trees were observed throughout the area that included park-like settings adjacent to the river and neighboring woodlots. A total of 46 dead stems ranging from 5.1 to $84 \mathrm{~cm}$ dbh were visually inspected for $A$. macer activity without felling the trees. Old egg masses and D-shaped exit holes, which are typical for Agrilus species, were observed on $82.6 \%$ of these trees. Among living trees, only those exhibiting symptoms of decline (e.g., thin or yellow crowns) had tan-colored A. macer egg masses, as also assessed from the ground. Trees under attack by A. macer (in which larvae are tunneling through the bark) were found weeping black liquid around the egg masses, as visible externally (Fig. 1c), but weeping was not observed in trees at later stages of attack. We also observed evidence of trees overcoming attacks by A. macer. This consisted of the formation of callus tissue beneath each mass, resulting in a raised bump in the bark (Fig. 1d, e).

\subsection{Abundance and distribution of egg masses}

The estimated number of egg masses present on the main stems (i.e., not including other branches, etc.) of the five trees ranged from 384 to 13,024 (Table 1). On the tree with highest density of egg masses, tree A (Table 1), there were about 1.2 masses for every $10 \mathrm{~cm}^{2}$ of bark, which is equivalent to about two eggs per square centimeter. Standardized egg mass density varied significantly with height along the bole $\left(F_{8,24}=\right.$ $3.59, P<0.01)$, being significantly higher at mid-bole positions $(2.7-2.9 \mathrm{~m}, 4.5-5.1 \mathrm{~m}, 7.1-7.3 \mathrm{~m}, 9.3-9.5 \mathrm{~m})$ than at the base or the upper reaches of the trees (Fig. 4).

\subsection{Number of eggs per mass}

The number of eggs or larvae counted per mass ranged from 5 to 28 , with an average of $16.1 \pm 0.4$ eggs per mass. The number of eggs per mass did not vary significantly with height above the ground $\left(F_{1,102}=1.67, P=0.2\right)$. 


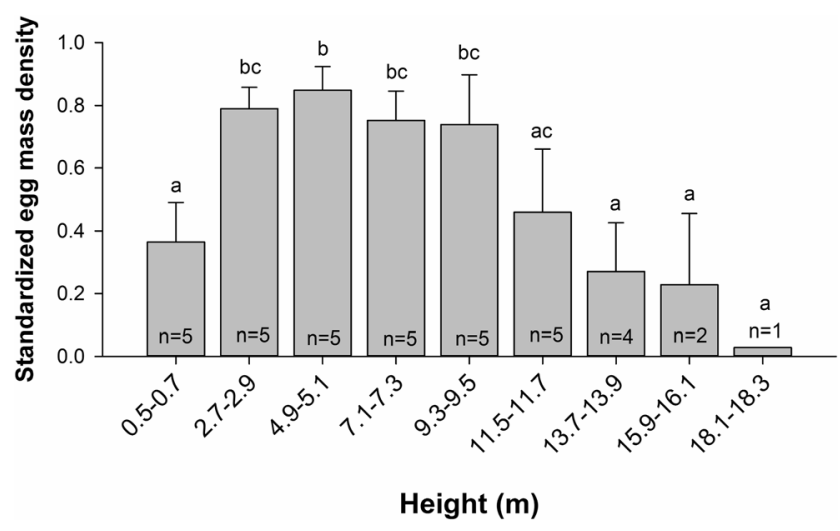

Fig. 4 Mean \pm SE standardized Agrilus macer egg mass density by height as measured from five trees. Bars with different letters above them are statistically significant based on differences of least square means

\subsection{Observations of $A$. macer egg-laying behavior}

Almost the entire sequence of egg-laying behavior was observed for three A. macer females in June 2016. The beetles lay their eggs on the smooth areas of bark of a declining tree, avoiding the natural warty bumps commonly found on sugarberry bark. A bright green substance, which is presumably leaf material since adults were observed feeding on sugarberry leaves, is defecated on top of the egg mass before the female begins applying a tan liquid as a final layer. This latter material is added with quick circular movements of the abdomen and quickly dries into the protective cap characteristic of the egg mass (Fig. 3).

\subsection{Adult activity period}

In our 2016 trapping effort, a total of 69 A. macer specimens were collected over the 16-week sampling period, with 40 and 29 being captured in the intercept and Lindgren funnel traps, respectively. The first specimen was not captured until June, and the largest number of specimens was collected between 15 and 28 June, which is a common activity time for other Agrilus species in the southeastern USA (Burke 1917; Klingeman et al. 2015; Nord et al. 1965). A single specimen was collected during our last sample period, 23 August to 9 September (Fig. 5).

\subsection{Agrilus macer distribution}

A total of 2032 specimens with applicable records and data were obtained from the collections listed in Acknowledgements. Although we received records of A. macer from nine southern US states, ranging from California in the west to South Carolina in the east (Fig. 6), almost all specimens $(98 \%)$ were collected in Louisiana (1126) or Texas (868) (Fig. 7). Texas had the highest number of county records (30), followed by Louisiana (3 parishes).
South Carolina had the next most records, although all but a single specimen from 1934 are recent specimens from our study area. There were five specimens each from Florida and Mississippi, whereas the other five states were each represented by just a single specimen. The specimen from Georgia was a recent record from near our study area.

\subsection{Oviposition behavior of selected Agrilus species}

Of the 25 Agrilus species for which egg-laying biology was found, 12 species lay eggs singly while the remaining species are known to sometimes or always lay clusters of eggs (Table 2). Agrilus macer appears to lay the largest number of eggs per cluster on average, but other species, such as A. biguttatus Fabricus and A. politus Say, are also known to lay large clusters of eggs. Six (30\%) of the 25 Agrilus species apply a secretion to the eggs, in addition to any secretion used to attach the eggs to the oviposition site (Table 2). While these are transparent secretions in most cases, the brown covering prepared by A. politus females is very similar to that produced by $A$. macer. Although A. macer is the only species known to deposit a layer of green substance over the eggs before smearing the final protective covering on the eggs, Dutt (1969) reported that female A. acutus Thunberg frequently deposit a "greenish-black elliptical fecal pellet" on the egg along with a fluid discharge.

\subsection{Fungal isolations and pathogenicity testing}

Three fungi isolated from the discolored areas around A. macer attack points and subsequently used in pathogenicity tests were identified as Clonostachys rosea, Fusarium neocosmosporiellum, and Phialemonium dimorphosporum. Clonostachys rosea was isolated from all sampled stem sections at the Lake Olmstead Park. This fungus was also isolated and identified from various stem and root samples from seven additional symptomatic trees along the Greeneway. Fusarium neocosmosporiellum and $P$. dimorphosporum were isolated from eight trees heavily attacked by the $A$. macer along the Greeneway. F. neocosmosporiellum was also confirmed from one of the Lake Olmstead Park trees.

Clonostachys rosea, F. neocosmosporiellum, and P. dimorphosporum were $99 \%, 98 \%$, and $99 \%$ similar to GenBank accession numbers EU552110.1 (C. rosea), KM231803.1 (F. neocosmosporiellum), and KX881590.1 (P. dimorphosporum), respectively. No dieback or leaf yellowing was observed in saplings of any inoculation treatment. Zones of discoloration were observed above and below the point of inoculation for fungal treatments and in the control treatment in both inoculation tests. The discolored area appeared as a fine black streak, which emanated from the inoculation point and was never more than a few millimeters in width. In test 1 , the length of the discolored sapwood in 
Fig. 5 Total number of Agrilus macer collected by sampling period in North Augusta (a) and by month based on museum records (b)
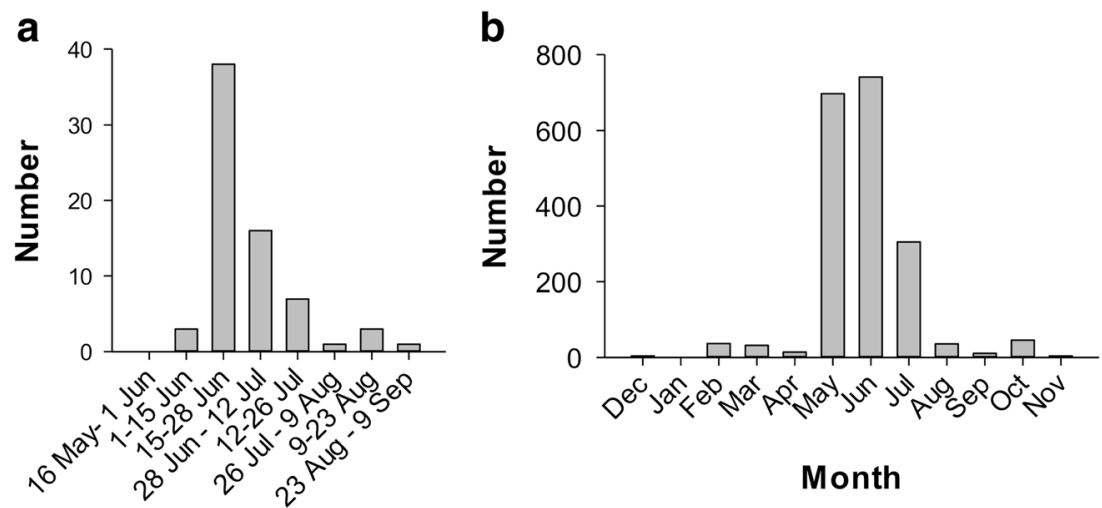

\section{Sample Period 2016}

saplings inoculated with $F$. neocosmosporiellum (18.2 \pm $1.2 \mathrm{~mm}$ ) was significantly greater than saplings in the control treatment $(8.97 \pm 1.1 \mathrm{~mm} ; P=0.0038)$; however, the length of the discoloration in saplings inoculated with $P$. dimorphosporum $(19.5 \pm 4.7 \mathrm{~mm})$ did not differ from control saplings $(P=0.2406)$. In test 2 , the length of the discoloration in saplings inoculated with $C$. rosea $(19.3 \pm 3.1 \mathrm{~mm}) \mathrm{did}$ not differ significantly from the discoloration length in the control saplings $(12.3 \pm 0.77 \mathrm{~mm} ; P=0.1093)$.

\section{Discussion}

To our knowledge, the density of eggs laid by A. macer on the trunks and stems of dying sugarberry exceed that reported for any other species of Agrilus. At the highest densities observed in this study, there were about 1.2 egg masses for every $10 \mathrm{~cm}^{2}$ of bark, which is equivalent to about two eggs per square centimeter. These numbers are especially surprising considering there was only a single record of $A$. macer from South Carolina from 1934, and there were no records of the species being in neighboring Georgia before the current episode of sugarberry mortality. From the information provided by collection specimens, A. macer appears to be widely distributed throughout the southern USA but has been most often collected in Texas and Louisiana. Specimens collected outside of sugarberry's native range were most likely found as a result of the presence of other Celtis species, as larvae have been previously recorded in C. occidentalis and C. tenuifolia (Harpootlian and Bellamy 2014). The abundance of stressed and dying host trees has clearly resulted in an unusual population increase for our study area.

Compared to most other members of the genus that have been studied, the egg masses laid by $A$. macer are also unusual in terms of the number of eggs laid per mass. Although there are approximately 3000 species of Agrilus worldwide, descriptive observations of the oviposition behavior and egglaying techniques are not often readily available for many species (Jendek 2016). Based on the available literature, about half of Agrilus species lay single eggs, whereas the rest are known to lay clusters of 2-30 eggs with typically few eggs per cluster. A. macer has the largest known average number of eggs per cluster with 16 eggs per mass. Most Agrilus species prefer to lay eggs within crevices on the host plant, but A. macer will attach egg clusters to smooth surfaces of bark. The eggs are then concealed with a tan secretion that hardens into a covering. The substance used to create this covering
Fig. 6 Known distribution of Agrilus macer based on museum specimens

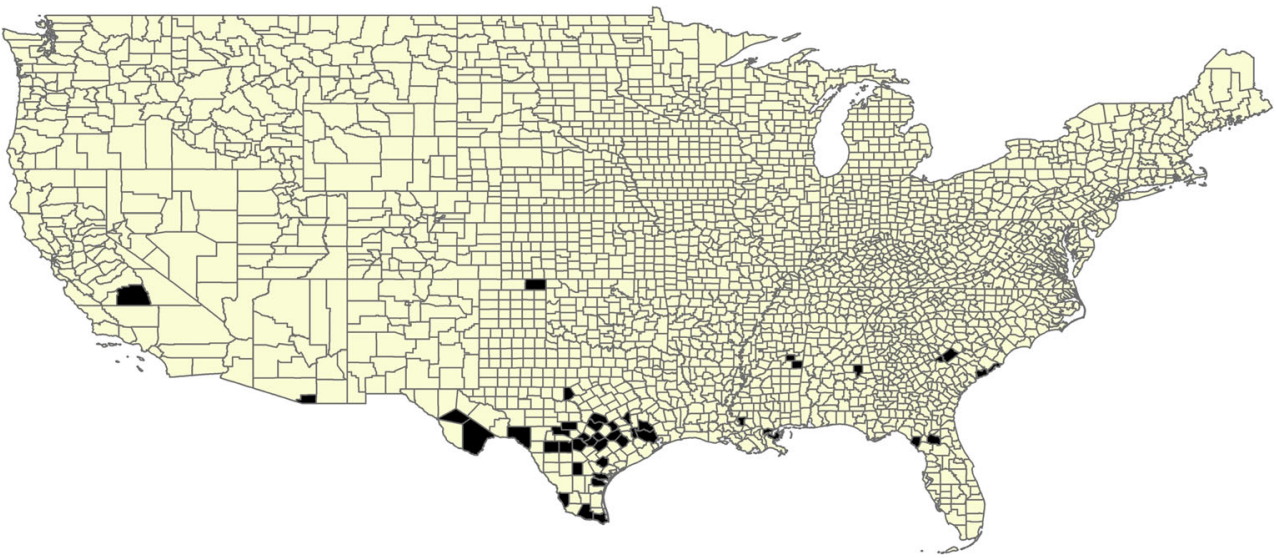




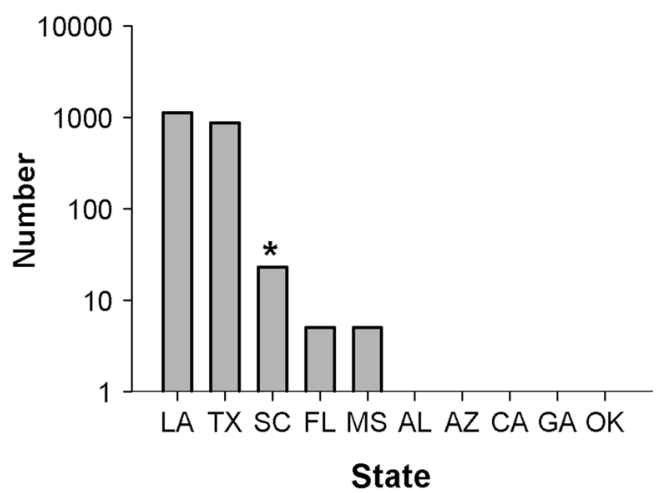

Fig. 7 Total number of Agrilus macer collected by state based on museum specimens. At least one specimen was collected from each state listed. Only one specimen was collected from South Carolina prior to this study

possibly originates from the accessory (colleterial) gland, considering that secretions from this gland are commonly used by insects to aid in egg adhesion (Hilker and Meiners 2002; Klowden 2013; Li et al. 2008). The cap presumably provides protection from environmental factors and natural enemies (Desurmont and Weston 2011), and we noticed ants readily attack masses with damaged caps.

Although not common among members of the genus, other species are also known to produce similar capped masses of eggs. The species with egg-laying behavior most similar to A. macer appears to be A. politus, which attacks willow and maple. Like A. macer, A. politus lays groups of eggs covered with a substance that hardens and creates a brown cap on the smooth bark of trunks and branches. While the advantage of producing such egg masses remains unknown, one possibility is attacking en masse helps to locally overcome host plant defenses. Gregarious larval feeding is not a common Agrilus mechanism but is noted in some Dendroctonus species as a behavior that increases the larval growth rate (Storer et al. 1997). Duan et al. (2010) showed host tree defenses, especially the formation of callus tissue, were the most important mortality factors for A. planipennis larvae. Furthermore, similar callus tissue has been observed as a response against $A$. biguttatus and A. auroguttatus egg masses and larval feeding on oak (Brown et al. 2015; Coleman and Seybold 2008). It is clear from our observations that trees are sometimes able to overcome colonization attempts, and attacks from A. macer do not guarantee the tree will soon die. The formation of callus tissue seems to be an important mechanism by which trees overcome attacks by A. macer (Fig. 1d, e), and this may have selected for the production of large egg masses by the species. To our knowledge, the green material we observed female A. macer adding on top of eggs has never been reported before, although the observation of A. acutus depositing a fecal pellet on top of individual eggs is similar (Dutt 1969). This material presumably consists of leaf material ingested by the female, but it remains unclear how this addition benefits the eggs or first instar larvae. It is possible that this material is simply voided before the tan secretion is expelled, as it is common for Agrilus species to feed on foliage of the host plant (Burke 1917; Petrice et al. 2009).

Based on our trapping effort in North Augusta, SC, the adult activity of $A$. macer was highest the week of 15-28 June in North Augusta. Similar to our observations, museum specimen labels indicate the species can be captured in low numbers in the warmer months of the year but is most abundant in May, June, and July.

The necrotic zones surrounding $A$. macer oviposition sites and associated streaks of discoloration in the xylem could be related to F. neocosmosporiellum, which is the only fungus to provide a significant increase in xylem discoloration following wounding and inoculation. Fusarium neocosmosporiellum is a pathogen in agricultural crops (Cheng and Schenck 1978; Smith 1899); however, our test is the first indication that $F$. neocosmosporiellum could be weakly pathogenic to a tree species. Other fungi such as $P$. dimorphosporum and C. rosea were also associated with the discolored sapwood following A. macer oviposition, and these fungi may also elicit a host response in sugarberry. Although the mean sapwood discoloration lengths in saplings inoculated with $P$. dimorphosporium and $C$. rosea did not differ from controls, the variation in the lengths following inoculation with these fungi was considerably greater than that observed in controls. Furthermore, $P$. dimorphosporum was reisolated from only two of four inoculated stems, and bacteria and yeasts predominated in stems from which $P$. dimorphosporium was not successfully reisolated. The lengths of discoloration in stems from which $P$. dimorphosporium was reisolated were greater than $24 \mathrm{~mm}$, thus suggesting that colonization by other organisms could have limited the ability of $P$. dimorphosporium to colonize host tissue in some inoculated saplings. Phialemonium dimorphosporium has been previously associated with bark beetle galleries and sapwood discoloration in conifer logs (Hutchison and Reid 1988) and is capable of causing soft rot in wood (Zabel et al. 1991). Clonostachys rosea is a cosmopolitan fungus frequently found in soil and on plant debris (Farr et al. 1990) and has been thought to be important as a biocontrol agent of plant diseases (Papavizas 1985), a mycoparasite (Jensen et al. 2000; Jensen et al. 2004), and a plant pathogen (Afshari and Hemmati 2017; Bienapfl et al. 2012). Nonetheless, none of the fungi that we isolated from discolored areas of affected sugarberries and subsequently tested in controlled inoculations had a significant effect on tree growth and health, and a possible role of these fungi in the current decline of sugarberry is doubtful. 


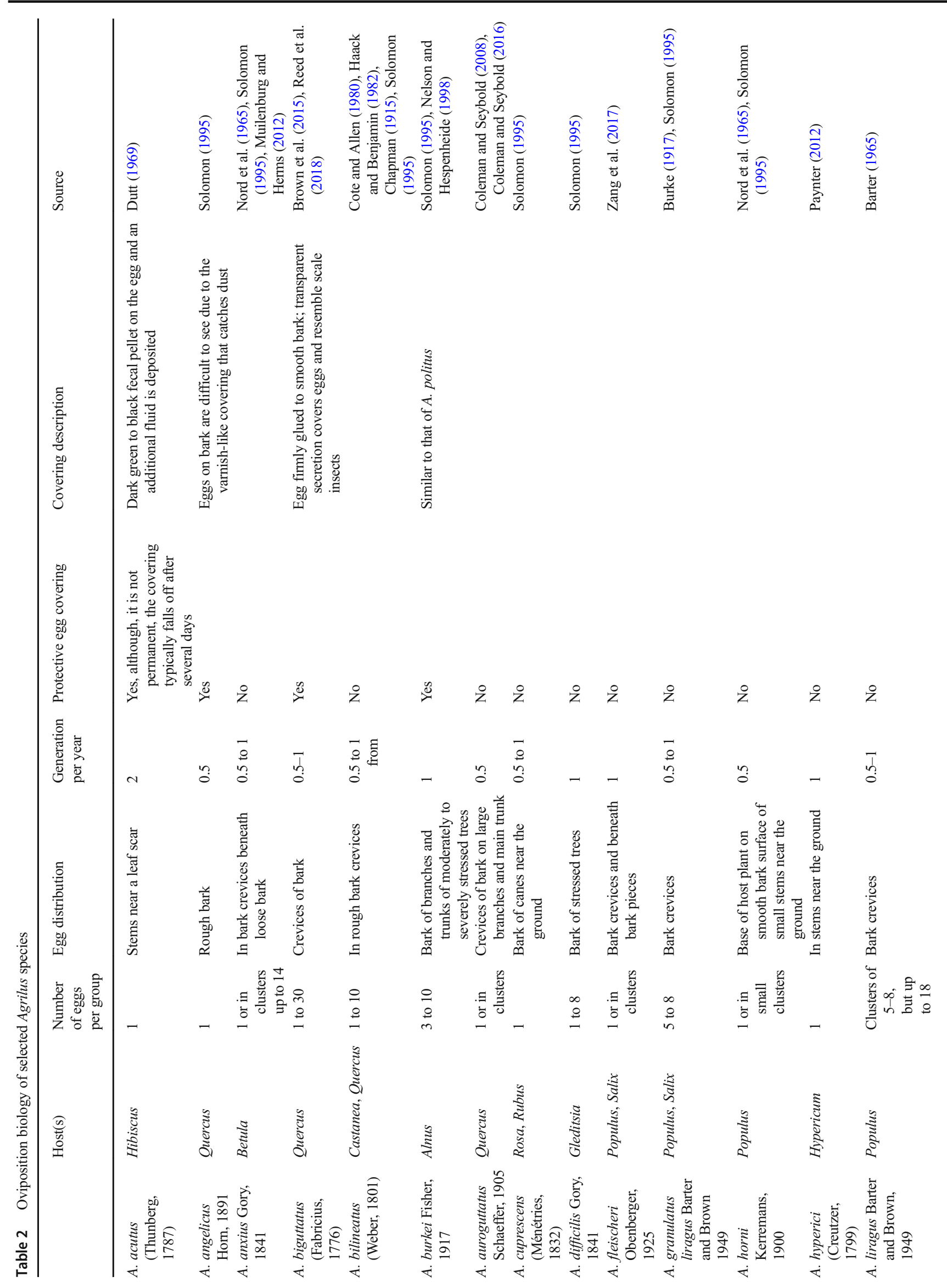




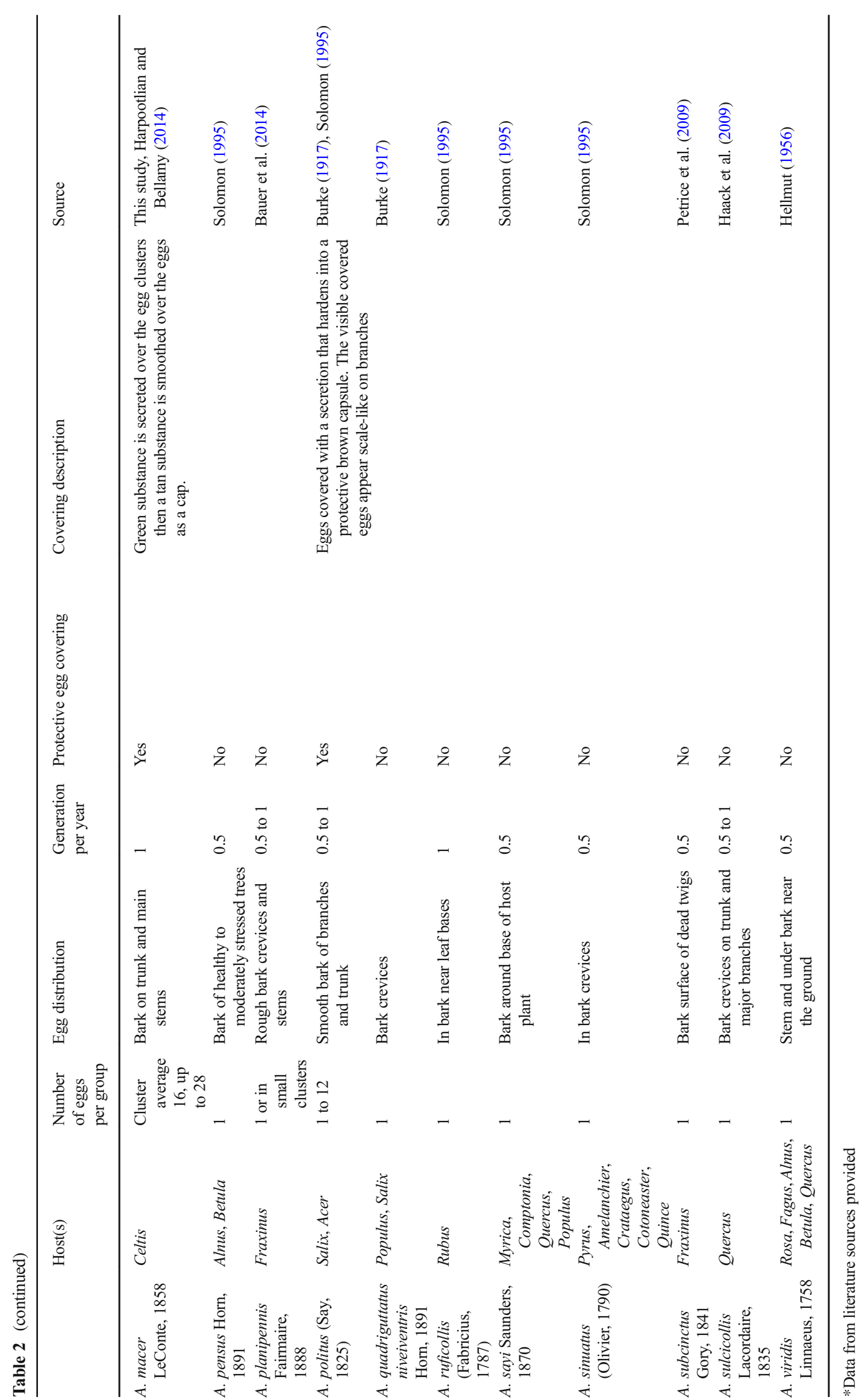




\section{Conclusion}

Although largely concentrated in Texas and Louisiana, A. macer appears to be widespread throughout the southern USA from California in the west to South Carolina in the east. Before the current episode of sugarberry mortality, A. macer was unknown from Georgia and had not been collected in South Carolina since 1934. This is in striking contrast to the incredible density of A. macer egg masses observed on weakened sugarberry in the current study. The rarity of $A$. macer in collections is not too surprising considering that methods for collecting buprestids are poorly developed. Indeed, it is clear from observations of buprestids captured by foraging Cerceris (Crabronidae) wasps that many buprestid species active in an area often go undetected by human collectors (Swink et al. 2013). It is therefore probable that A. macer is considerably more abundant and widespread than existing collection records indicate. Support for this comes from a recent Cerceris-based survey in Louisiana which found A. macer to be the most abundant buprestid species collected by the wasps (Johnson et al. 2015).

Because new and old egg masses, D-shaped exit holes, weeping wounds, and callused areas from previous attacks by $A$. macer are not obvious on all dying sugarberry in our study area (MDU and EMP, personal observations), there is no reason to believe that $A$. macer is the primary cause of mortality. This conclusion is supported by the fact relatively healthy trees are able to overcome attacks from the beetle and are generally avoided, as well as there being no evidence the beetles transmit a highly pathogenic fungus. The sapwood discoloration associated with beetle galleries is probably caused by the introduction of a weakly pathogenic fungus that causes a very limited host response, but these fungi do not appear to directly affect tree health.

It remains unknown what is responsible for the dying sugarberry in Georgia and South Carolina, and research into this question continues. While we do not believe A. macer plays a primary role in this mortality, the species does appear to act as an important contributing factor, and Chittenden (1900) reported the species to be "very injurious" to Celtis in Texas. The observation that some trees are able to overcome attacks by $A$. macer and can then live for years thereafter suggests that attacks by this beetle are not limited to extremely weakened trees (MDU personal observation). Moreover, by attacking at such high densities, A. macer may hasten the death of many trees, possibly preventing recovery in some cases.

Acknowledgements We thank Roy Kibler for permission to work along the Greeneway in North Augusta. We are also grateful to the following individuals for responding to our request for specimen information: Lee Herman (American Museum of Natural History), Melissa Callahan (Auburn University Natural History Museum), Jacqueline Airoso (California State Collection of Arthropods), Patrice Bouchard and Anthony Davies (Canadian National Collection of Insects, Arachnids, and Nematodes), John Rawlings and Robert Androw (Carnegie Museum of Natural History Invertebrate Collection), John Morse and Mike Ferro (Clemson University Arthropod Collection), Christopher Grinter (Entomology Collection of the California Academy of Sciences), Jim Louderman and Crystal Maier (Field Museum of Natural History Collection of Insects, Arachnids, and Myriapods and InvertEbase, NSF Award EF 14-02667), Rick Hoebeke (Georgia Natural History Museum), Philip Perkins (Harvard Museum of Comparative Zoology), Tommy McElrath (Illinois Natural History Survey Insect Collection), Louisiana State Arthropod Museum, Gary Parsons and Anthony Cognato (Albert J. Cook Arthropod Research Collection at Michigan State), Terence Lee Schiefer (Mississippi Entomological Museum), Weiping Xie and Brian Brown (Natural History Museum of Los Angeles County), Hellen Vessels (New Mexico State University Arthropod Collection), Bob Blinn (North Carolina State University Insect Collection), Luciana Musetti (Ohio State Triplehorn Insect Collection), Phil Mulder and Jana Slaughter (Oklahoma StateK.C. Emerson Entomology Museum), Robert Androw Private Collection, Charyn J. Micheli and Eugenio H. Nearns (Smithsonian National Museum of Natural History), Karen Wright (Texas A\&M Insect Collection), Texas Tech Insect Collection, Wendy Moore and Wesley E. Hall (University of Arizona), Michael S. Engel (University of Kansas Natural History Museum), and Stylianos Chatzimanolis (University of Tennessee Natural History Museum). Finally, we thank three anonymous reviewers for comments that greatly improved the manuscript.

Funding This research was funded by the USDA Forest Service, Southern Research Station including a grant from Forest Health Protection's Evaluation Monitoring program (SO-EM-17-04).

Data availability Datasets analyzed during the current study are available from the corresponding author upon request.

\section{Compliance with ethical standards}

Conflict of interest The authors declare that they have no conflict of interest.

\section{References}

Afshari N, Hemmati R (2017) First report of the occurrence and pathogenicity of Clonostachys rosea on faba bean. Australas Plant Path 46:231-234. https://doi.org/10.1007/s13313-017-0482-3

Baranchikov Y, Mozolevskaya E, Yurchenko G, Kenis M (2008) Occurrence of the emerald ash borer, Agrilus planipennis in Russia and its potential impact on European forestry. EPPO Bulletin 38:233-238. https://doi.org/10.1111/j.1365-2338.2008. 01210.x

Barter GW (1957) Studies of the bronze birch borer, Agrilus anxius Gory, in New Brunswick. Can Entomol 89:12-36

Barter GW (1965) Survival and development of the bronze poplar borer Agrilus liragus Barter \& Brown (Coleoptera: Buprestidae). Can Entomol 97:1063-1068

Bauer LS, Duan JJ, Gould JR (2014) Emerald ash borer (Agrilus planipennis Fairmaire) (Coleoptera: Buprestidae). In: Driesche RV, Reardon R (eds) The use of classical biol control to preserve forests in North America. U.S. Department of Agriculture, Forest Service, Morgantown, West Virginia, pp 189-209

Bienapfl JC, Floyd CM, Percich JA, Malvick DK (2012) First report of Clonostachys rosea causing root rot of soybean in the United 
States. Plant Dis 96:1700-1700. https://doi.org/10.1094/pdis-0612-0550-pdn

Billings RF, Grosman DM, Pase HA III (2014) Soapberry borer, Agrilus prionurus (Coleoptera: Buprestidae): an exotic pest threatens western soapberry in Texas. Southeast Nat 13:105-116

Brown N, Inward DJG, Jeger M, Denman S (2015) A review of Agrilus biguttatus in UK forests and its relationship with acute oak decline. Forestry 88:53-63. https://doi.org/10.1093/forestry/cpu039

Burke HE (1917) Notes on some western Buprestidae. J Econ Entomol 10:325-332. https://doi.org/10.1093/jee/10.3.325

Chapman RN (1915) Observations of the life history of Agrilus bilineatus. J Agric Res 3:283-293

Cheng Y, Schenck N (1978) Effect of soil temperature and moisture on survival of the soybean root rot fungi Neocosmospora vasinfecta and Fusarium solani in soil. Plant Dis Rep 62:945-949

Chittenden FH (1900) Food plants and injury of North American species of Agrilus. United States Department of Agriculture, Division of Entomology 64-68. Washington DC

Coleman T, Seybold J, S (2008) Previously unrecorded damage to oak, Quercus spp., in southern California by the goldspotted oak borer, Agrilus coxalis Waterhouse (Coleoptera: Buprestidae). Pan-Pac Entomol 84:288-300. https://doi.org/10.3956/2008-18.1

Coleman TW, Seybold SJ (2016) Goldspotted oak borer in California: Invasion history, biology, impact, management, and implications for Mediterranean forests worldwide. In: Paine T, Lieutier F (eds) Insects and diseases of Mediterranean forest systems. Springer, Cham, pp 663-697. https://doi.org/10.1007/978-3-319-24744-1_22

Cote IWA, Allen DC (1980) Biology of two-lined chestnut borer, Agrilus bilineatus, in Pennsylvania and New York. Ann Entomol Soc Am 73:409-413. https://doi.org/10.1093/aesa/73.4.409

Desurmont GA, Weston PA (2011) Aggregative oviposition of a phytophagous beetle overcomes egg-crushing plant defences. Ecol Entomol 36:335-343. https://doi.org/10.1111/j.1365-2311.2011.01277.x

Duan JJ, Ulyshen MD, Bauer LS, Gould J, Driesche RV (2010) Measuring the impact of biotic factors on populations of immature emerald ash borers (Coleoptera: Buprestidae). Environ Entomol 39: 1513-1522. https://doi.org/10.1603/en10023

Duncan WH, Duncan MB (1988) Trees of the southeastern United States. University of Georgia Press, Athens

Dutt DK (1969) Bionomics of Agrilus acutus (Thnb.) (Col., Buprestidae) on mesta (Hibiscus cannabinus) in India. Bull Entomol Res 58:421430. https://doi.org/10.1017/s0007485300057187

Farr DF, Bills GF, Chamuris GP, Rossman AY (1990) Fungi on plants and plant products in the United States. J Bot Taxo Geobotany 101:340 340. https://doi.org/10.1002/fedr.19901010703

Ford AL, Van Auken OW (1982) The distribution of woody species in the Guadalupe River Floodplain Forest in the Edwards Plateau of Texas. Southwest Nat 27:383-392. https://doi.org/10.2307/3670713

Gardes M, Bruns TD (1993) ITS primers with enhanced specificity for basidiomycetes - application to the identification of mycorrhizae and rusts. Mol Ecol 2:113-118. https://doi.org/10.1111/j.1365294X.1993.tb00005.x

Haack RA (2006) Exotic bark-and wood-boring Coleoptera in the United States: recent establishments and interceptions. Can J For Res 36: 269-288

Haack RA, Benjamin DM (1982) The biology and ecology of the twolined chestnut borer, Agrilus bilineatus (Coleoptera: Buprestidae) on oaks, Quercus spp. In: Wisconsin. The Can Entomol, vol 114, pp 385-396. https://doi.org/10.4039/Ent114385-5

Haack RA, Petrice TR, Zablotny JE (2009) First report of the European oak borer, Agrilus sulcicollis (Coleoptera: Buprestidae), in the United States. Great Lakes Entomol 42:1-7

Harpootlian PJ, Bellamy CL (2014) Jewel beetles (Coleoptera: Buprestidae) of South Carolina. Clemson University Clemson. In: SC
Hellmut H (1956) Zur biologie, Ökologie und zum massenwechsel des buchenpracht käfers (Agrilus viridis L.): II. Teil. Z Angew Entomol 39:76-114. https://doi.org/10.1111/j.1439-0418.1956.tb01244.x

Hespenheide H, Westcott R, L. Bellamy C (2011) Agrilus Curtis (Coleoptera: Buprestidae) of the Baja California peninsula, Mexico. Zootaxa 2805:36-56

Hilker M, Meiners T (2002) Chemoecology of insect eggs and egg deposition. Chemoecology 12:220-220. https://doi.org/10.1007/ p100013846

Hizal E, Arslangündoğdu Z (2018) The first record of two-lined chestnut borer Agrilus bilineatus (Weber, 1801) (Coleoptera: Buprestidae) from Europe. Entomol News 127:333-335

Hutchison LJ, Reid J (1988) Taxonomy of some potential wood-staining fungi from New Zealand 2. Pyrenomycetes, coelomycetes and hyphomycetes. NZ J Bot 26:83-98. https://doi.org/10.1080/0028825x. 1988.10410100

Jendek E (2016) Taxonomic, nomenclatural, distributional and biological study of the genus Agrilus (Coleoptera: Buprestidae). J Ins Biodiv 4(2):1-57. https://doi.org/10.12976/jib/2016.4.2

Jensen B, Knudsen IMB, Jensen DF (2000) Biological seed treatment of cereals with fresh and long-term stored formulations of Clonostachys rosea: biocontrol efficacy against Fusarium culmorum. Eur J Plant Pathol 106:233-242. https://doi.org/10. 1023/a:1008794626600

Jensen B, Knudsen IMB, Madsen M, Jensen DF (2004) Biopriming of infected carrot seed with an antagonist, Clonostachys rosea, selected for control of seedborne Alternaria spp. Phytopathology 94:551560

Johnson CW, MacRae TC, Brownie C, Virgets W, Allison JD (2015) Observations of Cerceris fumipennis (Hymenoptera: Crabronidae) phenology and variation in its buprestid prey in Louisiana. Fla Entomol 98:1106-1113. https://doi.org/10.1653/024.098.0415

Klingeman WE, Hansen JA, Basham JP, Oliver JB, Youseff NN, Swink W, Nalepa CA, Fare DC, Moulton JK (2015) Seasonal flight activity and distribution of metallic woodboring beetles (Coleoptera: Buprestidae) collected in North Carolina and Tennessee. Fla Entomol 98:579-587

Klowden MJ (2013) Chapter 4 - reproductive systems. In: Klowden MJ (ed) Physiological Systems in Insects, Third edn. Academic Press, San Diego, pp 197-254. https://doi.org/10.1016/B978-0-12415819-1.00004-0

Li D, Huson M, Graham L (2008) Proteinaceous adhesive secretions from insects, and in particular the egg attachment glue of Opodiphthera sp. moths. Arch Insect Biochem 69:85-105. https:// doi.org/10.1002/ach.20267

Muilenburg VL, Herms DA (2012) A review of bronze birch borer (Coleoptera: Buprestidae) life history, ecology, and management. Environ Entomol 41:1372-1385

Nelson GE, Hespenheide HA (1998) A re-evaluations of some Agrilus Curtis species (Coleoptera: Buprestidae). Col Bull 52:31-34 The Coleopterists Society

Nelson PE, Marasas WFO, Toussoun TA (1983) Fusarium species: an illustrated manual for identification. Pennsylvania State University Press, University Park

Nord JC, Knight FB, Vogt GB (1965) Identity and biology of an aspen root girdler, Agrilus horni. Forest Sci 11:33-34. https://doi.org/10. 1093/forestscience/11.1.33

Papavizas GC (1985) Trichoderma and Gliocladium: biology, ecology, and potential for biocontrol. Annu Rev Phytopathol 23:23-54. https://doi.org/10.1146/annurev.py.23.090185.000323

Paynter Q (2012) Biological control of weeds in Australia. Aust J Entomol 51:221-221. https://doi.org/10.1111/j.1440-6055.2012. 00868.x

Petrice TR, Haack RA, Strazanac JS, Lelito JP (2009) Biology and larval morphology of Agrilus subcinctus (Coleoptera: Buprestidae), with 
7 Page 14 of 14

Annals of Forest Science (2019) 76: 7

comparisons to the emerald ash borer, Agrilus planipennis. Great Lakes Entomol 42:173-184

Reed K, Denman S, Leather SR, Forster J, Inward DJG (2018) The lifecycle of Agrilus biguttatus: the role of temperature in its development and distribution, and implications for acute oak decline. Agric and Forest Entomol 20:334-346. https://doi.org/10.1111/afe. 12266

Samuelson LJ, Hogan ME (2003) Forest trees: a guide to the southeastern and mid-Atlantic regions of the United States. Pearson Education, Inc., Upper Saddle River, N.J

Smith EF (1899) Wilt disease of cotton, watermelon and cowpea (Neocosmospora nov. gen.). United States Department of Agriculture Bull. No. 17: 1-53

Solomon JD (1995) Guide to insect borers in North American broadleaf trees and shrubs. Agriculture handbook: AH-706. U.S. Department of Agriculture, Forest Service, Washington, DC

Solomon JD, Wilson AD, Leininger TD, Lester DG, McCasland CS, Clarke S, Affeltranger C (1997) Sugarberry dieback and mortality in southern Louisiana: Cause, impact, and prognosis. Res. Pap. SRS-9. Asheville, NC: U.S. Department of Agriculture, Forest Service, Southern Research Station. $19 \mathrm{p}$

Stores AJ, Wainhouse D, Speight MR (1997) The effect of larval aggiegation behaviour on larval growth of the spruce bark beetle Dendroctonus micans. Ecol Entomol 22:109-115. https://oi.org/ 10.1046/j.1365-2311.1997.00036.x

Swink WG, Paiero SM, Nalepa CA (2013) Buprestidae collected as prey by the solitary, ground-nesting Philanthine wasp Cerceris fumipennis (Hymenoptera: Crabronidae) in North Carolina. Ann Entomol Soc Am 106:111-116. https://doi.org/10.1603/an12113

Tirmenstein DA (1990) Celts laevigate var. reticulate. In: Fire Effects Information System. U.S. Department of Agriculture, Forest Service, Rocky Mountain Research Station, Fire Sciences Laboratory (Producer). Available: https://www.fs.fed.us/database/ feis/plants/tree/cellaer/all.html

Vogt GB (1949) A biologically annotated list of the Buprestidae of the lower Rio Grande Valley, Texas. Ann Entomol Soc Am 42:191-202

White TJ, Buns T, Lee S, Taylor J (1990) 38 -amplification and direct sequencing of fungal ribosomal RNA genes for phylogenetic In: Innis MA, Gelfand DH, Sninsky JJ, White TJ (eds) PCR Protocols. Academic Press, San Diego, pp 315-322. https://doi.org/10.1016/ B978-0-12-372180-8.50042-1

Zabel R, Wang C, Anagnost S (1991) Soft-rot capabilities of the major microfungi isolated from Douglas-fir poles in the northeast. Wood Fiber Sci 13:220-237

Rang K, Wang X-Y, Yang Z-Q, Wei K, Dunn JJ (2017) Biology and natural enemies of Agrilus fleischer (Coleoptera: Buprestidae), a newly emerging destructive buprestid pest in Northeast China. J Asia Pac Entomol 20:47-52

Publisher's note Springer Nature remains neutral with regard to jurisdictonal claims in published maps and institutional affiliations.

Springer

IRA

science e IMPACI 